\title{
Mimicking of Phase I Metabolism Reactions of Molindone by HLM and Photocatalytic Methods with the Use of UHPLC-MS/MS
}

\author{
Maciej Gawlik ${ }^{1}$, Vladimir Savic ${ }^{2}$, Milos Jovanovic ${ }^{2}$ and Robert Skibiński ${ }^{1, *(D)}$ \\ 1 Department of Medicinal Chemistry, Faculty of Pharmacy, Medical University of Lublin, Jaczewskiego 4, \\ 20-090 Lublin, Poland; maciej.gawlik@umlub.pl \\ 2 Department of Organic Chemistry, Faculty of Pharmacy, University of Belgrade, Vojvode Stepe 450, \\ 11221 Belgrade, Serbia; vladimir.savic@pharmacy.bg.ac.rs (V.S.); milos.jovanovic@pharmacy.bg.ac.rs (M.J.) \\ * Correspondence: robert.skibinski@umlub.pl; Tel.: +48-81-4487390; Fax: +48-81-4487380
}

Academic Editor: Tomasz Tuzimski

Received: 14 February 2020; Accepted: 15 March 2020; Published: 17 March 2020

\begin{abstract}
Establishing the metabolism pathway of the drug undergoing the hepatic biotransformation pathway is one of the most important aspects in the preclinical discovery process since the presence of toxic or reactive metabolites may result in drug withdrawal from the market. In this study, we present the structural elucidation of six, not described yet, metabolites of an antipsychotic molecule: molindone. The elucidation of metabolites was supported with a novel photocatalytical approach with the use of $\mathrm{WO}_{3}$ and $\mathrm{WS}_{2}$ assisted photochemical reactions. An UHPLC-ESI-Q-TOF combined system was used for the registration of all obtained metabolite profiles as well as to record the high resolution fragmentation spectra of the observed transformation products. As a reference in the in vitro metabolism simulation method, the incubation with human liver microsomes was used. Chemometric comparison of the obtained profiles pointed out the use of the $\mathrm{WO}_{3}$ approach as being more convenient in the field of drug metabolism studies. Moreover, the photocatalysis was used in the direction of the main drug metabolite synthesis in order to further isolation and characterization.
\end{abstract}

Keywords: photocatalysis; metabolites; HLM; mass spectrometry; chemometric analysis

\section{Introduction}

Molindone (3-ethyl-2-methyl-5-(morpholin-4-ylmethyl)-1,5,6,7-tetrahydroindol-4-one) is a medicine originally and mainly used in schizophrenia treatment. In addition, its use is also considered in ADHD therapy (attention-deficit/hyperactivity disorder) [1-3]. The mechanism of molindone action assumes $\mathrm{D}_{2 \mathrm{~S}}, \mathrm{D}_{2 \mathrm{~L}}, \mathrm{D}_{5}$ dopamine, and 5- $\mathrm{HT}_{2 \mathrm{~B}}$ serotonin receptor antagonist activity and remains strictly in correlation with the dopamine hypothesis of schizophrenia [4-9]. It should also be noted that patients treated with molindone are exposed to the occurrence of side effects, for instance, tardive dyskinesia or akathisia, according to the commonly known mechanism of neuroleptics dopamine antagonistic potential [10-12]. The drug is considered to undergo the hepatic metabolism pathway and its use in treatment should be monitored due to possible hepatotoxic impact [13,14]. Nevertheless, molindone reveals activity corresponding to leading antipsychotics and does not influence weight gain, which is an infrequent property in the field of neuroleptic drugs [15,16]. As molindone has been introduced anew to market and is used in schizophrenia therapy, the issue of the hepatotoxicity origin is still not better known.

Moreover, the liver is an organ that is mainly responsible for drug metabolism, intoxification, and preparing to excrete intermediates from the human organism. The medicine molecule participating in biochemical processes changes its physicochemical properties, which can be responsible for the 
formation of toxic metabolites [17-20]. As these multidirectional processes occur and at the same time lead to the formation of many derivatives, a detailed understanding of the transformation pathways of a medicinal compound as well as metabolites brings knowledge of both the mechanisms of drug action and underlies further research on the drug. The activity that the liver shows in the metabolism of medicines has become the basis for developing an in vitro assay for determining drug metabolism [21]. The human liver microsomes (HLMs) used for this purpose provide satisfactory results with reference to drug molecules undergoing the hepatic pathway [22-24]. In spite of its unequivocal usefulness in drug metabolism studies, this approach also reflects minor drawbacks. Due to the co-presence of biological interferences such as cell matrix, proteins, and phospholipids, the use of HLM incubation in metabolite isolation is a complex process and requires a time-consuming workflow [25]. Additionally, the explicit decrease in reaction efficiency relative to the incubation time further limits the use of this method as an simple and effortless source of metabolites [26].

The further attempts to decrease severe costs associated with drug development studies have contributed to involve photo-assisted catalysis with the use of metal oxide nanoparticles in metabolism simulation processes [27-30]. This new approach benefits from economic efficiency, a simple procedure, and also requires less human resources. The principle of this method is based on metal oxide semiconductor properties with the ability to create reactive oxygen species (ROS) in aqueous solution and under simultaneous adequate UV irradiation [31,32]. Generated radicals act as a strong oxidizing agents and cause molecule oxidation in the presence of the tested drug substance in solution. Despite the fact that heterogeneous photocatalysis was originally applied in drug metabolism studies with the use of model substance Degussa P25 titanium dioxide $\left(\mathrm{TiO}_{2}\right)$, tungsten oxide $\left(\mathrm{WO}_{3}\right)$ assisted photocatalysis turned out to provide satisfactory and promising results $[33,34]$. The synthesis and isolation of metabolites is a distinct issue. Since the conventional approach of obtaining metabolites assumes organic synthesis, some modern techniques such as biosynthesis, enzymatic methods, and electrochemical (EC) synthetic reactions are particularly gaining attention [35-40]. In this context, the photocatalytic transformation of drugs in order to further metabolite isolation seems to become a promising tool. This method simplifies the procedure and given the lack of the use of any organic solvents, conforms to the principles of green chemistry.

The aim of this study was to develop a simple, fast, and cheap method for preliminary drug metabolism research. The detailed molindone metabolism pathway was established in accordance with $\mathrm{WO}_{3}$ and tungsten disulfide $\left(\mathrm{WS}_{2}\right)$ ssisted photocatalysis. Furthermore, the feasibility of study, assuming the use of the photocatalytic protocol in order to further metabolite isolation, was successfully confirmed. In addition, structural elucidation of molindone metabolites was carried out based on the ultra-high-pressure liquid chromatography-electrospray ionization-quadrupole time-of-flight-mass spectrometry (UHPLC-ESI-Q-TOF MS) combined system, which is a highly useful tool in drug metabolism studies [41-44].

\section{Results and Discussion}

\subsection{Photocatalytic Degradation Kinetics}

In the pilot study, the adsorption of molindone on $\mathrm{WO}_{3}$ and $\mathrm{WS}_{2}$ was tested in the 0-60 min time range and no significant differences were found in the concentrations of the analyzed compound. Therefore, a $60 \mathrm{~min}$ adsorption-desorption equilibrium time was defined for both catalyzed samples. Subsequently, the degradation kinetics were studied within the given time ranges of 0-20 min for $\mathrm{WO}_{3}$ and 0-30 min for the $\mathrm{WS}_{2}$ photocatalytic experiments. The obtained results show that the photocatalytic decomposition of molindone yielded pseudo-first kinetics for the $\mathrm{WO}_{3}$ assisted $\left(k=0.1634 \mathrm{~min}^{-1}\right.$, $\left.\mathrm{t}_{1 / 2}=4.3 \mathrm{~min}, \mathrm{r}=0.9532\right)$ and $\mathrm{WS}_{2}$ assisted $\left(k=0.0129 \mathrm{~min}^{-1}, \mathrm{t}_{1 / 2}=63 \mathrm{~min}, \mathrm{r}=0.9948\right)$ photochemical reaction (Figure 1). 


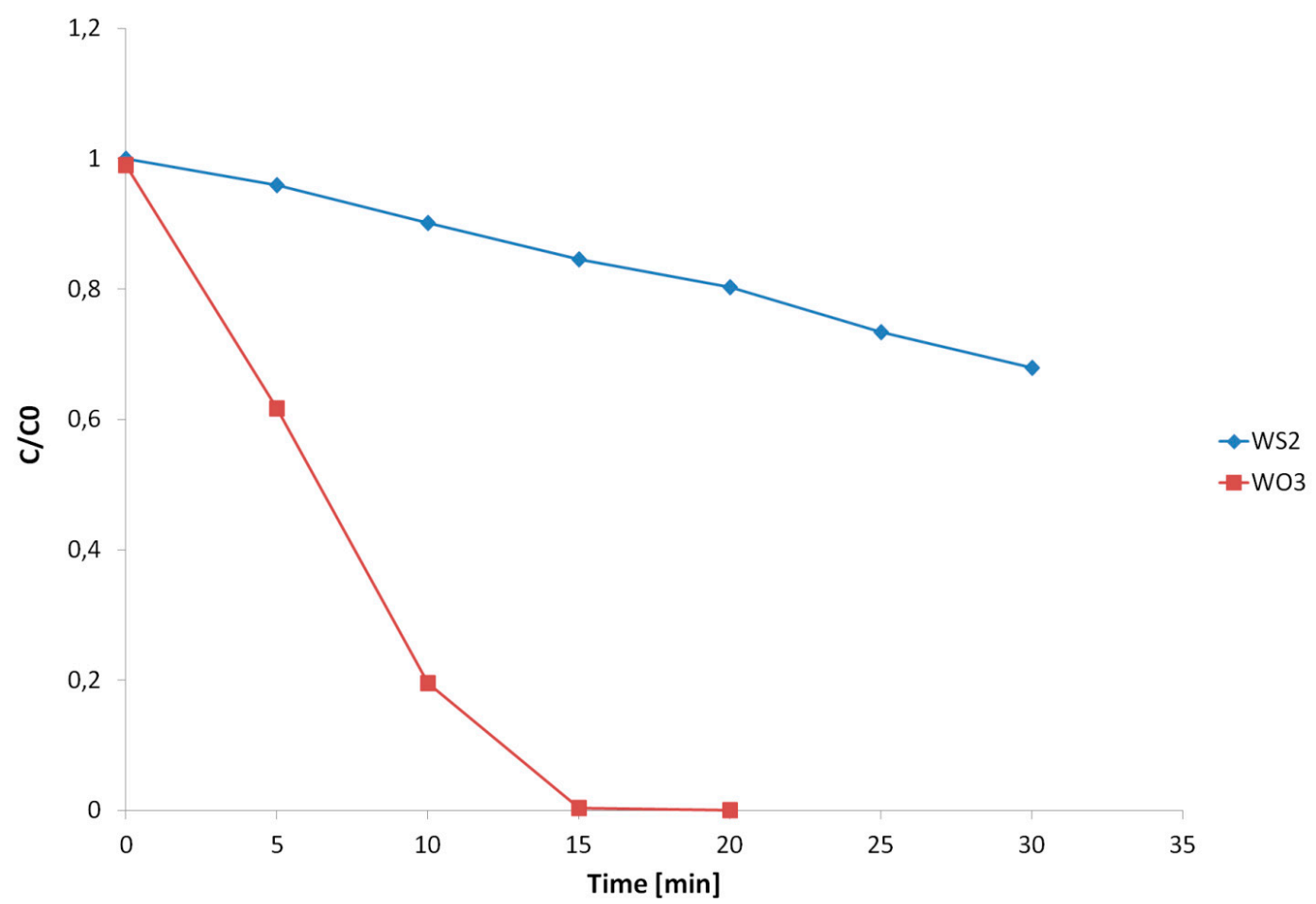

Figure 1. Kinetics of molindone photocatalytic decomposition presented as a normalized concentration $\left(\mathrm{C} / \mathrm{C}_{0}\right)$ against time $(\mathrm{min})$.

\subsection{Multivariate Comparison of Human Liver Microsome (HLM) Metabolites and Photocatalytic Products}

In order to perform a preliminary comparison between $\mathrm{WS}_{2}$ and $\mathrm{WO}_{3}$ photo-assisted catalysis with regard to the HLM metabolite profile of molindone, a multivariate chemometric analysis was performed. All of the obtained chromatographic profiles (24 chromatograms) registered in time-of-flight (MS) mode were aligned with Mass Profiler Professional (MPP) software, giving 176 entities. After a build-in MPP filtration including sample abundance and the Mann-Whitney u-test $(p<0.05$, FC $>1.1)$, 17 entities were finally selected for the chemometric study. The PCA analysis based on this data showed a visible categorization of all of the analyzed groups of the registered metabolic profiles (Figure 2). Two types of photocatalytic profiles remained in a short distance from each other, however, the samples belonging to $\mathrm{WO}_{3}$ inducted photocatalysis were closer to the HLM samples. Negative control samples (Cont) stood out from the other profiles, which confirmed the occurrence of metabolic reactions. The achieved results suggest that $\mathrm{WO}_{3}$ photocatalytic profiles are substantially more similar to hepatic metabolism profiles than $\mathrm{WS}_{2}$. In the presented principal component analysis (PCA), the first three components (PC) explained $95.0 \%$ of the total variance.

Taking this into account, the proposed $\mathrm{WO}_{3}$ photocatalytic method could be considered as a more suitable approach for mimicking the phase I metabolism reactions. Moreover, considering the degradation kinetic parameters (Section 2.1), this catalyst is also more suitable for the production and isolation of the main metabolites of molindone. 


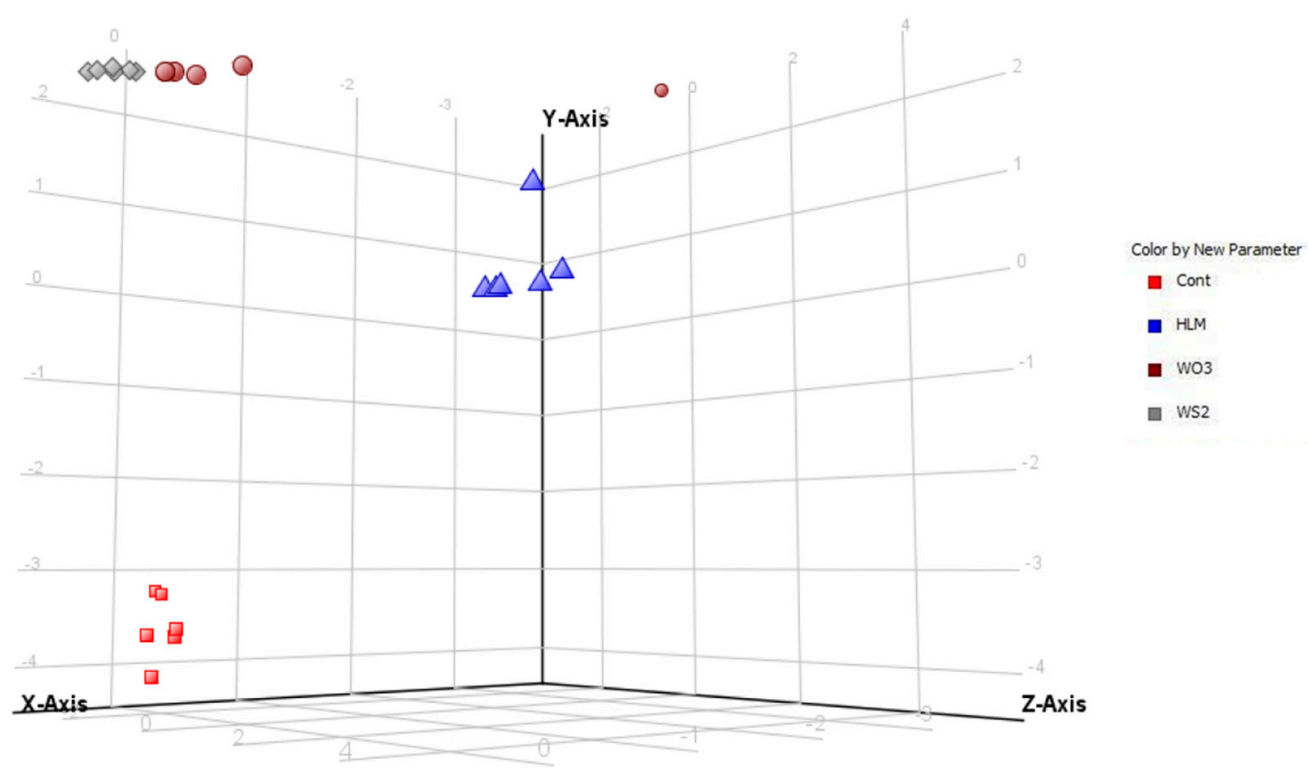

Figure 2. PCA plot of HLM (blue triangles), $\mathrm{WS}_{2}$ (grey diamonds), and $\mathrm{WO}_{3}$ (brown spheres) with the control group (red squares) profiles of molindone.

\subsection{Metabolites Identification}

Six metabolites of molindone were identified in this study. Metabolite structures were elucidated by UHPLC-ESI-Q-TOF analysis with the use of recorded high resolution MS/MS spectra. The fragmentation patterns of molindone and its metabolites are summarized in Table 1, and an example of the total ion chromatogram obtained for the HLM experiment is presented in Figure 3.

In order to perform accurate structural elucidation of the main metabolite (M1), an additional $\mathrm{WO}_{3}$ assisted photocatalytic experiment was performed. Based on our preliminary photocatalysis optimization process, the loading level of the parent compound as well as the irradiation time were increased, which provided the opportunity to obtain a semi-preparative level of this metabolite (Section 3.2). Next, the ultra-fast liquid chromatography (UFLC) reversed-phase system was used for M1 isolation; after evaporation and dissolution in deuterated methanol, 1H NMR spectroscopy was carried out. 
Table 1. Q-TOF accurate mass elemental composition and MS/MS fragmentation and of the analyzed substances.

\begin{tabular}{|c|c|c|c|c|c|c|c|c|}
\hline Name & Reaction Type & $\begin{array}{l}\text { Retention Time } \\
\text { [min] }\end{array}$ & $\begin{array}{c}\text { Measured Mass } \\
{[\mathrm{m} / \mathrm{z}]}\end{array}$ & $\begin{array}{l}\text { Theoretical } \\
\text { Mass }[\mathrm{m} / \mathrm{z}]\end{array}$ & $\begin{array}{l}\text { Mass Error } \\
\text { [ppm] }\end{array}$ & $\begin{array}{c}\text { Molecular Formula } \\
{[\mathrm{M}+\mathrm{H}]^{+}}\end{array}$ & $\begin{array}{c}\text { MS/MS } \\
\text { Fragmentation }[\mathrm{m} / \mathrm{z}]\end{array}$ & $\begin{array}{l}\text { Fragmentation Ion } \\
\text { Formula }[\mathrm{M}+\mathrm{H}]^{+}\end{array}$ \\
\hline MO & - & 6.53 & 277.1910 & 277.1910 & 0.00 & $\mathrm{C}_{16} \mathrm{H}_{24} \mathrm{~N}_{2} \mathrm{O}_{2}$ & \begin{tabular}{c|}
190.1206 \\
176.1057 \\
116.0708 \\
100.0761 \\
82.0657 \\
70.0658
\end{tabular} & $\begin{array}{c}\mathrm{C}_{12} \mathrm{H}_{16} \mathrm{NO} \\
\mathrm{C}_{11} \mathrm{H}_{14} \mathrm{NO} \\
\mathrm{C}_{5} \mathrm{H}_{10} \mathrm{NO}_{2} \\
\mathrm{C}_{5} \mathrm{H}_{10} \mathrm{NO} \\
\mathrm{C}_{5} \mathrm{H}_{8} \mathrm{~N} \\
\mathrm{C}_{4} \mathrm{H}_{8} \mathrm{~N}\end{array}$ \\
\hline M1 & $\mathrm{Al}-\mathrm{OH}$ & 2.50 & 293.1860 & 293.1859 & 0.34 & $\mathrm{C}_{16} \mathrm{H}_{25} \mathrm{~N}_{2} \mathrm{O}_{3}$ & $\begin{array}{c}275.1726 \\
221.1169 \\
160.0605 \\
100.0761 \\
70.0660\end{array}$ & $\begin{array}{c}\mathrm{C}_{16} \mathrm{H}_{23} \mathrm{~N}_{2} \mathrm{O}_{2} \\
\mathrm{C}_{12} \mathrm{H}_{17} \mathrm{~N}_{2} \mathrm{O}_{2} \\
\mathrm{C}_{9} \mathrm{H}_{8} \mathrm{~N}_{2} \mathrm{O} \\
\mathrm{C}_{5} \mathrm{H}_{10} \mathrm{NO} \\
\mathrm{C}_{4} \mathrm{H}_{8} \mathrm{~N}\end{array}$ \\
\hline M2 & Dealk & 5.24 & 251.1762 & 251.1754 & 3.18 & $\mathrm{C}_{14} \mathrm{H}_{23} \mathrm{~N}_{2} \mathrm{O}_{2}$ & $\begin{array}{c}178.1220 \\
160.1132 \\
122.0929 \\
74.0610 \\
\end{array}$ & $\begin{array}{c}\mathrm{C}_{11} \mathrm{H}_{16} \mathrm{NO} \\
\mathrm{C}_{11} \mathrm{H}_{14} \mathrm{NO} \\
\mathrm{C}_{8} \mathrm{H}_{12} \mathrm{~N} \\
\mathrm{C}_{3} \mathrm{H}_{8} \mathrm{NO}\end{array}$ \\
\hline M3 & $\mathrm{Al}-\mathrm{OH}$ & 4.90 & 293.2012 & 293.1859 & 52.18 & $\mathrm{C}_{16} \mathrm{H}_{25} \mathrm{~N}_{2} \mathrm{O}_{3}$ & $\begin{array}{c}206.1131 \\
194.1113 \\
188.1022 \\
100.0760 \\
74.0586\end{array}$ & $\begin{array}{c}\mathrm{C}_{12} \mathrm{H}_{16} \mathrm{NO}_{2} \\
\mathrm{C}_{11} \mathrm{H}_{16} \mathrm{NO}_{2} \\
\mathrm{C}_{12} \mathrm{H}_{14} \mathrm{NO} \\
\mathrm{C}_{5} \mathrm{H}_{10} \mathrm{NO} \\
\mathrm{C}_{3} \mathrm{H}_{8} \mathrm{NO}\end{array}$ \\
\hline M4 & $\begin{array}{l}\text { Al-2OH } \\
\text { Dehydrog }\end{array}$ & 3.32 & 307.1654 & 307.1652 & 0.65 & $\mathrm{C}_{13} \mathrm{H}_{23} \mathrm{~N}_{2} \mathrm{O}_{4}$ & $\begin{array}{c}289.1458 \\
188.1040 \\
100.0759 \\
84.0793 \\
\end{array}$ & $\begin{array}{c}\mathrm{C}_{16} \mathrm{H}_{21} \mathrm{~N}_{2} \mathrm{O}_{3} \\
\mathrm{C}_{12} \mathrm{H}_{14} \mathrm{NO} \\
\mathrm{C}_{5} \mathrm{H}_{10} \mathrm{NO} \\
\mathrm{C}_{5} \mathrm{H}_{10} \mathrm{~N} \\
\end{array}$ \\
\hline M6 & $\begin{array}{c}\text { Al-OH } \\
\text { Dehydrog }\end{array}$ & 3.70 & 291.1694 & 275.1754 & -3.09 & $\mathrm{C}_{16} \mathrm{H}_{23} \mathrm{~N}_{2} \mathrm{O}_{2}$ & $\begin{array}{l}204.1039 \\
176.1069 \\
162.0896 \\
136.0735 \\
100.0760 \\
188.1036 \\
100.0769\end{array}$ & $\begin{array}{l}\mathrm{C}_{12} \mathrm{H}_{14} \mathrm{NO}_{2} \\
\mathrm{C}_{11} \mathrm{H}_{14} \mathrm{NO} \\
\mathrm{C}_{10} \mathrm{H}_{12} \mathrm{NO} \\
\mathrm{C}_{8} \mathrm{H}_{10} \mathrm{NO} \\
\mathrm{C}_{5} \mathrm{H}_{10} \mathrm{NO} \\
\mathrm{C}_{12} \mathrm{H}_{14} \mathrm{NO} \\
\mathrm{C}_{5} \mathrm{H}_{10} \mathrm{NO}\end{array}$ \\
\hline
\end{tabular}




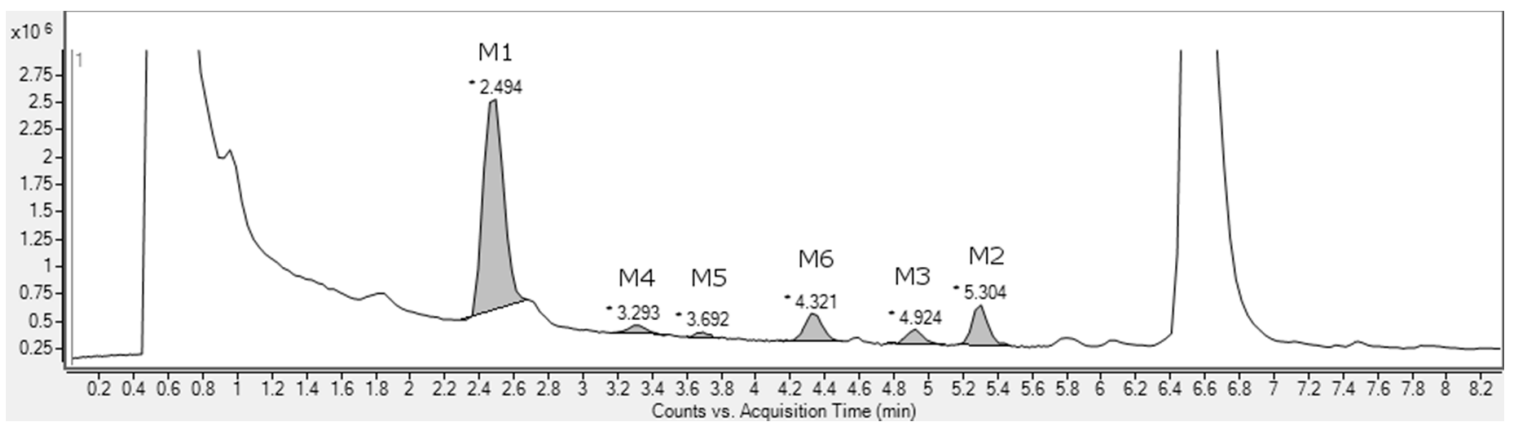

Figure 3. Total ion chromatogram obtained for HLM experiment.

The protonated molecular ion for molindone (Figure S1) was observed at $\mathrm{m} / \mathrm{z} 277.1910$ $\left(\mathrm{C}_{16} \mathrm{H}_{24} \mathrm{~N}_{2} \mathrm{O}_{2}[\mathrm{M}+\mathrm{H}]^{+}\right)$and the fragmentation at $16.9 \mathrm{eV}$ collision-induced dissociation (CID) energy resulted in methylmorpholine moiety detachment, which corresponded to the most abundant ion in the spectrum $\left(m / z 100.0761, \mathrm{C}_{5} \mathrm{H}_{10} \mathrm{NO}[\mathrm{M}+\mathrm{H}]^{+}\right)$and its further decomposition finally led to 2-(methylamino)prop-2-en-1-ylium ion formation $\left(\mathrm{m} / \mathrm{z} 70.0658, \mathrm{C}_{4} \mathrm{H}_{8} \mathrm{~N}[\mathrm{M}+\mathrm{H}]^{+}\right)$. In addition, parent molecule fragmentation also resulted in \{3-[(2-hydroxyethyl)amino]propylidyne\}oxidanium ion formation $\left(\mathrm{m} / z \mathrm{z} 116.0708, \mathrm{C}_{5} \mathrm{H}_{10} \mathrm{NO}_{2}[\mathrm{M}+\mathrm{H}]^{+}\right)$. The ion with $\mathrm{m} / z 190.1206\left(\mathrm{C}_{12} \mathrm{H}_{16} \mathrm{NO}[\mathrm{M}+\mathrm{H}]^{+}\right)$is another product of the morpholine moiety loss and its decomposition gradually led to the formation of the 2-methyl-1H-pyrrol-1-ium ion $\left(\mathrm{m} / z\right.$ 82.0657, $\left.\mathrm{C}_{5} \mathrm{H}_{8} \mathrm{~N}[\mathrm{M}+\mathrm{H}]^{+}\right)$.

The main metabolite, $\mathrm{M} 1\left(\mathrm{~m} / \mathrm{z} 293.1860, \mathrm{C}_{16} \mathrm{H}_{25} \mathrm{~N}_{2} \mathrm{O}_{3}[\mathrm{M}+\mathrm{H}]^{+}\right)$, was identified as a aliphatic hydroxyl derivative of molindone, 3-ethyl-2-(hydroxymethyl)-5-[(morpholin-4-yl)methyl]-1,5,6, 7-tetrahydro-4H-indol-4-one (Figure S2). The hydroxylation occurred in aliphatic methyl side chain of the compound. The ion with $m / z 275.1726\left(\mathrm{C}_{16} \mathrm{H}_{23} \mathrm{~N}_{2} \mathrm{O}_{2}[\mathrm{M}+\mathrm{H}]^{+}\right)$testifies to the hydroxyl group detachment and its morpholine ring decomposition resulted in ions with $m / z 221.1169\left(\mathrm{C}_{12} \mathrm{H}_{17} \mathrm{~N}_{2} \mathrm{O}_{2}[\mathrm{M}+\mathrm{H}]^{+}\right)$formation and then in structural rearrangement of the 4,5-dihydro-1H-pyrano[3,4-b]pyrrolo[2,3-d]pyrrol-7-ylium radical ion $\left(\mathrm{m} / \mathrm{z} 160.0605, \mathrm{C}_{9} \mathrm{H}_{8} \mathrm{~N}_{2} \mathrm{O}\right.$ $\left.[\mathrm{M}+\mathrm{H}]^{+}\right)$. The ion with $m / z$ 100.0761, $\left(\mathrm{C}_{5} \mathrm{H}_{10} \mathrm{NO}[\mathrm{M}+\mathrm{H}]^{+}\right)$was the most visible peak, similar to that in the parent molecule spectrum.

${ }^{1} \mathrm{H}$ NMR analysis also confirmed the introduction of the hydroxyl group in the methyl substituent in position 2 of the tetrahydroindol-4-one ring. First of all, absence of the distinct singlet signal of the above methyl group in the region $\delta 2.1$ was observed, and simultaneously, the characteristic singlet for the hydroxymethyl group at $\delta 4.57$ was registered. The presence of the ethyl group was confirmed by typical signals at $\delta 1.03(\mathrm{t}, J=10 \mathrm{~Hz})$ and $\delta 2.62(\mathrm{q}, J=10 \mathrm{~Hz})$. Two multiplets corresponding to the prochiral $\mathrm{CH}_{2}, \beta$ to the pyrrole ring, appeared at $\delta 1.95 / 2.19$. The observed multiplet at $\delta 3.82(4 \mathrm{H})$ belongs to the morpholine moiety while the remaining hydrogens appear as multiplets at $\delta 2.75-3.15$.

The M2 metabolite $\left(m / z 251.1762, \mathrm{C}_{14} \mathrm{H}_{23} \mathrm{~N}_{2} \mathrm{O}_{2}[\mathrm{M}+\mathrm{H}]^{+}\right)$was identified as a result of morpholine ring cleavage (Figure S3). The ion with $m / z 178.1220\left(\mathrm{C}_{11} \mathrm{H}_{16} \mathrm{NO}[\mathrm{M}+\mathrm{H}]^{+}\right)$was the most abundant ion in the spectrum and testifies to morpholine ring loss. Its further fragmentation led to the formation of ions with $m / z 160.1132\left(\mathrm{C}_{11} \mathrm{H}_{14} \mathrm{NO}[\mathrm{M}+\mathrm{H}]^{+}\right)$and $m / z 122.0929\left(\mathrm{C}_{8} \mathrm{H}_{12} \mathrm{~N}[\mathrm{M}+\mathrm{H}]^{+}\right)$. The ion with $\mathrm{m} / z$ $74.0610\left(\mathrm{C}_{3} \mathrm{H}_{8} \mathrm{NO}[\mathrm{M}+\mathrm{H}]^{+}\right)$as the result of the aforementioned morpholine ring cleavage was also clearly visible.

The M3 metabolite $\left(m / z\right.$ 293.2012, $\left.\mathrm{C}_{16} \mathrm{H}_{25} \mathrm{~N}_{2} \mathrm{O}_{3}[\mathrm{M}+\mathrm{H}]^{+}\right)$was identified as another hydroxyl derivative of molindone with substitution most likely located in position $\mathrm{C}-7$ in the cyclohexyl ring (Figure S4). The fragmentation lead to methylmorpholine moiety detachment $\left(\mathrm{m} / \mathrm{z} 100.0760, \mathrm{C}_{5} \mathrm{H}_{10} \mathrm{NO}\right.$ $\left.[\mathrm{M}+\mathrm{H}]^{+}\right)$with its following degradation to ions with $\mathrm{m} / z$ 74.0586 $\left(\mathrm{C}_{3} \mathrm{H}_{8} \mathrm{NO}[\mathrm{M}+\mathrm{H}]^{+}\right)$. The further decomposition of the ion with $m / z 206.1131\left(\mathrm{C}_{12} \mathrm{H}_{16} \mathrm{NO}_{2}\right)$, formed as a second fragment of morpholine moiety detachment from the parent compound, led to the formation of the ion with $\mathrm{m} / \mathrm{z} 194.1113$ $\left(\mathrm{C}_{11} \mathrm{H}_{16} \mathrm{NO}_{2}[\mathrm{M}+\mathrm{H}]^{+}\right)$with the remaining hydroxyl group. 
The M4 metabolite $\left(m / z 307.1654, \mathrm{C}_{13} \mathrm{H}_{23} \mathrm{~N}_{2} \mathrm{O}_{4}[\mathrm{M}+\mathrm{H}]^{+}\right)$was identified as a dihydroxy derivative of molindone (Figure S5). Dehydrogenation with a double bond formation in the tetrahydroindol-4-one ring is the second reaction that took place regarding the parent compound structure. Its fragmentation gradually led to both the removal of the hydroxyl groups, and the ion with $m / z 289.1458\left(\mathrm{C}_{16} \mathrm{H}_{21} \mathrm{~N}_{2} \mathrm{O}_{3}\right.$ $\left.[\mathrm{M}+\mathrm{H}]^{+}\right)$testifies to the first step of this process. The ion with $\mathrm{m} / \mathrm{z} 188.1040\left(\mathrm{C}_{12} \mathrm{H}_{14} \mathrm{NO}[\mathrm{M}+\mathrm{H}]^{+}\right)$ was a product of the second hydroxyl group and morpholine moiety detachment simultaneously with the double bond retained. Furthermore, the ion with $m / z 100.0759\left(\mathrm{C}_{5} \mathrm{H}_{10} \mathrm{NO}[\mathrm{M}+\mathrm{H}]^{+}\right)$was the most abundant ion in recorded spectrum.

The M5 metabolite $\left(m / z 291.1694, \mathrm{C}_{16} \mathrm{H}_{23} \mathrm{~N}_{2} \mathrm{O}_{3}[\mathrm{M}+\mathrm{H}]^{+}\right)$was identified as a hydroxyl substituted molindone most likely located in position C-7 in the cyclohexyl ring (Figure S6). Dehydrogenation in the tetrahydroindol-4-one ring was the second reaction that occurred with regard to the parent compound. The most abundant ion with $m / z 100.0760\left(\mathrm{C}_{5} \mathrm{H}_{10} \mathrm{NO}[\mathrm{M}+\mathrm{H}]^{+}\right)$belonged to the detached methylmorpholine moiety, whereas the fragment with $m / z 204.1039\left(\mathrm{C}_{12} \mathrm{H}_{14} \mathrm{NO}_{2}[\mathrm{M}+\mathrm{H}]^{+}\right)$testifies to the retention of the double bond and hydroxyl group in the second part of the fragmented metabolite structure. Further fragmentation of this ion consisted of two paths. One led to hydroxyl group detachment and the ion with $m / z 176.1069\left(\mathrm{C}_{11} \mathrm{H}_{14} \mathrm{NO}[\mathrm{M}+\mathrm{H}]^{+}\right)$was formed in this case. The second path assumed rearrangement with the formation of the ion at $\mathrm{m} / \mathrm{z} 162.0896$ $\left(\mathrm{C}_{10} \mathrm{H}_{12} \mathrm{NO}[\mathrm{M}+\mathrm{H}]^{+}\right)$, followed by additional rearrangement resulting in the formation of the 5-ethyl-6-(hydroxymethyl)pyridin-3-ylium ion ( $m / z$ 136.0735, $\mathrm{C}_{8} \mathrm{H}_{10} \mathrm{NO}[\mathrm{M}+\mathrm{H}]^{+}$)

The protonated molecular ion for the M6 metabolite was observed at $m / z\left(275.1754, \mathrm{C}_{16} \mathrm{H}_{23} \mathrm{~N}_{2} \mathrm{O}_{2}\right.$ $[\mathrm{M}+\mathrm{H}]^{+}$). Measured $\mathrm{m} / \mathrm{z}$ and the generated formula indicated the presence of an unsaturated bond located in the tetrahydroindol-4-one ring. The mild fragmentation at $10.0 \mathrm{eV} \mathrm{CID} \mathrm{energy} \mathrm{resulted} \mathrm{in}$ methylmorpholine moiety detachment, which corresponded to the ion with $m / z 100.0769\left(\mathrm{C}_{5} \mathrm{H}_{10} \mathrm{NO}\right.$ [M $\left.+\mathrm{H}^{+}\right)$. The rest of the metabolite structure with $m / z 188.1036\left(\mathrm{C}_{12} \mathrm{H}_{14} \mathrm{NO}\right)$ was also visible (Figure S7).

\subsection{Transformation Pathways}

The study resulted in the confirmation of one major and five minor metabolites of molindone obtained during microsomal incubation. As shown in Table 1, the parent compound underwent several metabolic reactions: hydroxylation (M1 and M3), dealkylation (M2), combination of hydroxylation and dehydrogenation (M4 and M5), and dehydrogenation (M6). It was noticeable that the aliphatic hydroxylation process was found to be the process responsible for the main metabolite (M1) formation (Figure 4A), and this reaction was successfully simulated with the use of both photocatalysts. The multivariate chemometric comparison of the distribution of this metabolite in the analyzed photocatalytic samples also confirmed their similarity to the biological experiment (Figure 5). Moreover, the $\mathrm{WO}_{3}$ assisted photocatalysis allowed us to observe four minor metabolites (M3, M4, M5, and M6), whereas the $\mathrm{WS}_{2}$ assisted photocatalysis allowed to observe three minor metabolites (M3, M5, and M6). It should be also noted that the photocatalytic methods significantly improved the identification of the minor metabolites due to their higher abundances and better detection with the use of the MS method. 

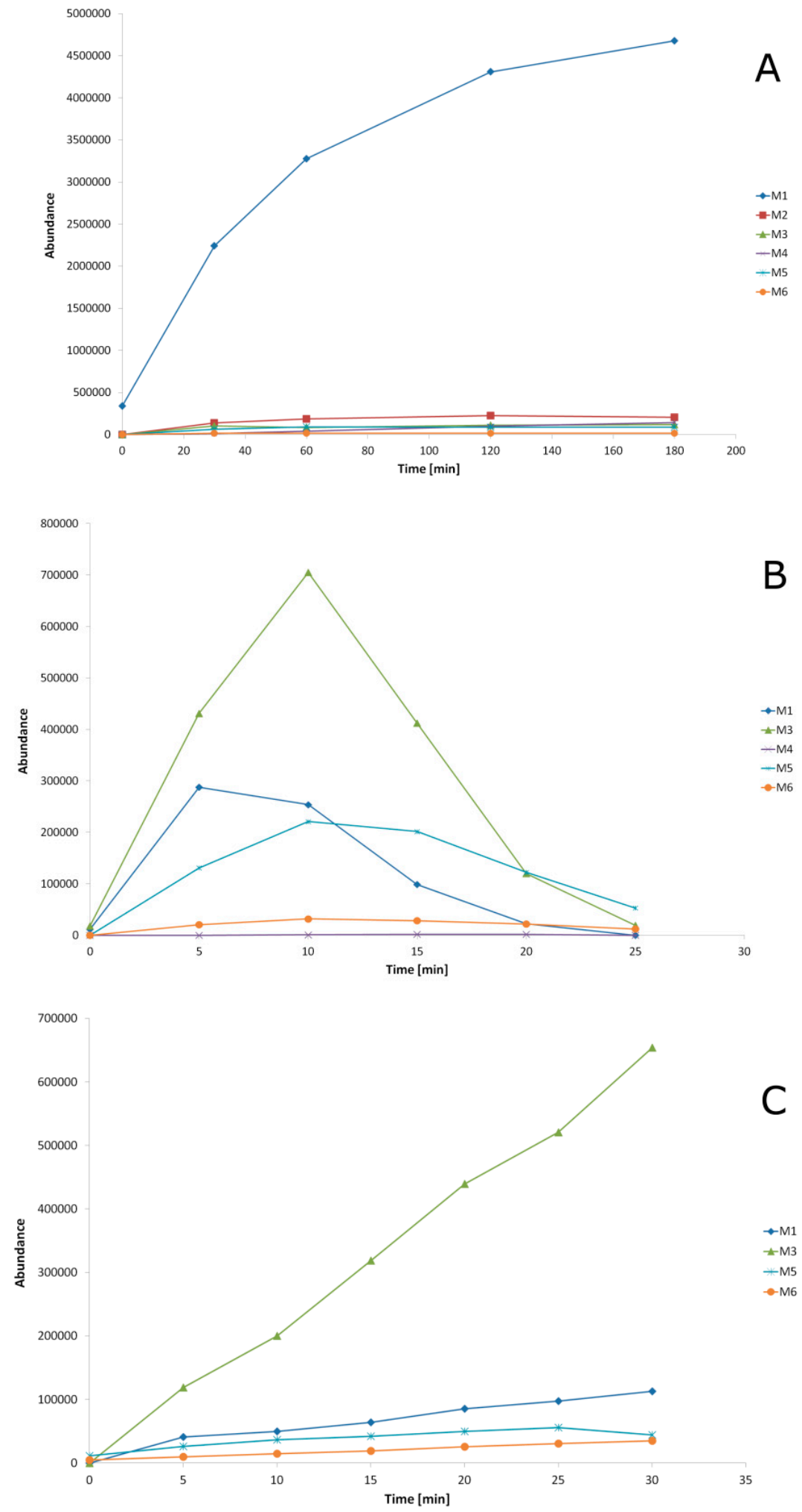

Figure 4. Evolution profiles of molindone metabolites formed during HLM incubation (A), $\mathrm{WO}_{3}$ assisted (B), and $\mathrm{WS}_{2}$ assisted photochemical reaction $(\mathbf{C})$. 


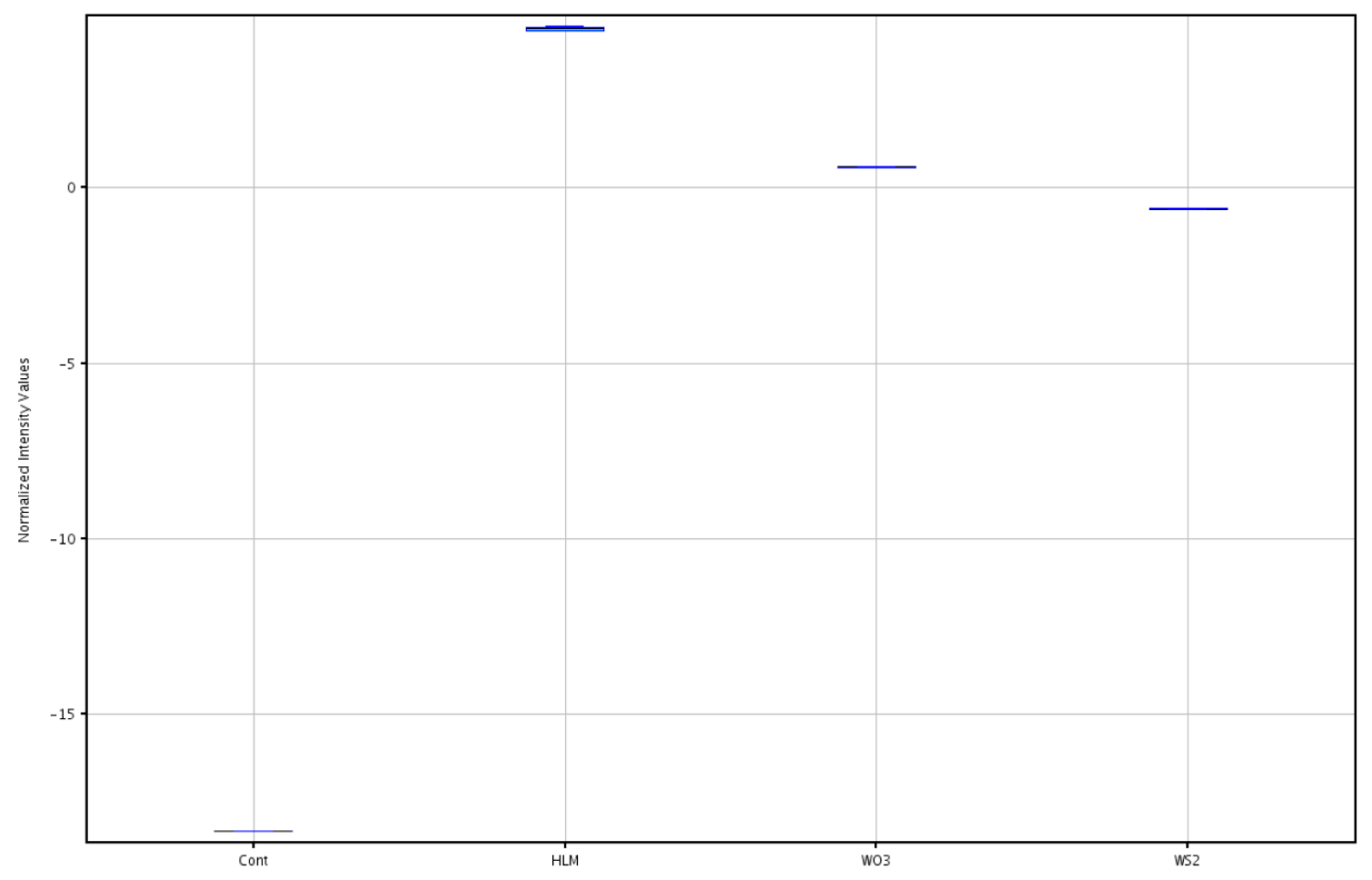

Figure 5. Box whisker plot of the relative intensity values of the main metabolite (M1) in the analyzed profiles (Control group, $\mathrm{HLM}, \mathrm{WO}_{3}, \mathrm{WS}_{2}$ ) of molindone.

The proposed metabolic pathway of molindone is presented in Figure 6. 


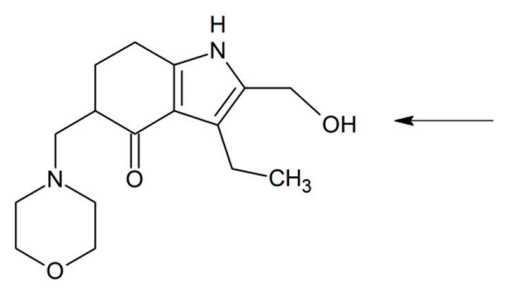

M1

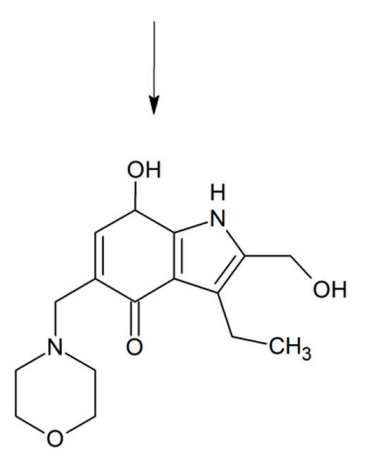

M4

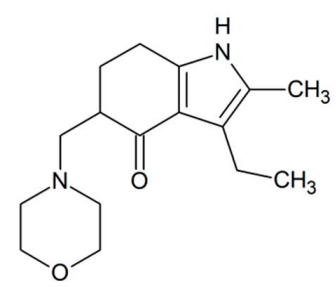

Molindone

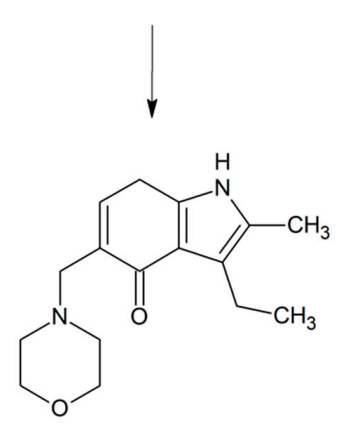

M6

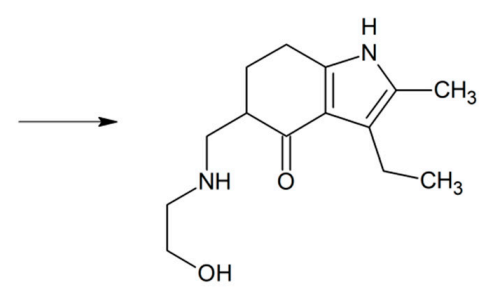

M2

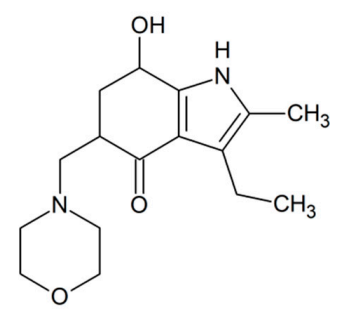

M3

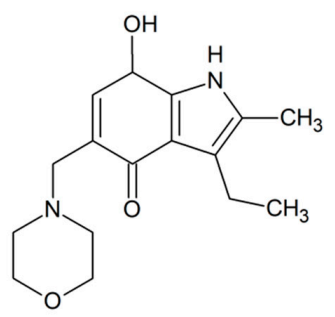

M5

Figure 6. The proposed metabolic pathway of molindone. 


\section{Materials and Methods}

\subsection{Chemicals and Reagents}

Molindone hydrochloride was obtained from Toronto Chemicals (Toronto, ON, Canada). Water (LC-MS Ultra grade), $\beta$-nicotinamide adenine dinucleotide 2 '-phosphate reduced tetrasodium salt hydrate (NADPH), human liver microsomes (HLMs), sodium phosphate monobasic monohydrate salt, sodium phosphate dibasic anhydrous salt, and tungsten (VI) oxide nanopowder $<100 \mathrm{~nm}$ particle size were obtained from Sigma-Aldrich (St. Louis, MO, USA). Tungsten disulfide (IV) nanopowder 40-80 nm particle size, amorphous was obtained from U.S. Research Nanomaterials, Inc. (Houston, TX, USA). Acetonitrile (hypergrade for LC-MS), were purchased from Merck (Darmstadt, Germany) and $98 \%$ formic acid (mass spectroscopy grade) was obtained from Fluka (Taufkirchen, Germany).

\subsection{Photocatalytic Experiments}

The photocatalytic reactions were performed in the aqueous solution at a concentration of $25 \mu \mathrm{M}$ of the tested drugs. The applied catalyst loadings were set to $100 \mathrm{mg} \mathrm{L}^{-1}$ of $\mathrm{WO}_{3}$ and $100 \mathrm{mg} \mathrm{L}^{-1}$ of $\mathrm{WS}_{2}$. For all experiments, suspensions were transferred into $3.5 \mathrm{~mL}$ quartz caped cells $(1=1 \mathrm{~cm})$ and stirred at $500 \mathrm{rpm}$ (microstirrer Cimarel: Telemodul, Thermo Electron LED GmbH, Osterode am Harz, Germany) in the dark for $60 \mathrm{~min}$ to achieve adsorption-desorption equilibrium. Next, reaction cells were mounted horizontally in an Atlas Suntest CPS+ photostability chamber with a D65 filter (Linsengericht, Hesse, Germany), and irradiated simultaneously with stirring. The irradiance was set to $765 \mathrm{~W} \mathrm{~m}^{-2}$, which corresponded to an energy dose of $2854 \mathrm{~kJ} \mathrm{~m}^{-2} \mathrm{~h}^{-1}$. The temperature in the chamber was controlled and kept below $35^{\circ} \mathrm{C}$. Aliquots $(100 \mu \mathrm{L})$ were collected at proper intervals and the following time ranges were set to: $0-25 \mathrm{~min}$ for $\mathrm{WO}_{3}$ and 0-30 min for $\mathrm{WS}_{2}$ photocatalytic experiments. All suspensions were then centrifuged at 15,000 rpm for 5 min (Eppendorf 5424R, Germany), $50 \mu \mathrm{L}$ aliquots were collected, and UHPLC-ESI-Q-TOF analysis was performed.

In order to perform the isolation of the main metabolite (M1), $2 \mathrm{mg} \mathrm{mL}^{-1}$ solution of molindone with the addition of $\mathrm{WO}_{3}$ was irradiated for $6 \mathrm{~h}$ under the same conditions and next semi-preparative chromatography was realized.

\subsection{In Vitro Simulation of Metabolism by Human Liver Microsomes}

Phase I metabolism reactions were performed in vitro with the use of the HLM fraction. The incubation system consisted of $50 \mu \mathrm{M}$ substrate, $55 \mathrm{mM}$ phosphate buffer ( $\mathrm{pH} 7.4$ ), and $0.5 \mathrm{mg} \mathrm{mL}^{-1}$ microsomes. The incubation system was pre-incubated at $37^{\circ} \mathrm{C}$ for $2 \mathrm{~min}$ (Eppendorf ThermoMixer $\mathrm{C}$ equipped with Eppendorf ThermoTop, Hamburg, Germany) and then the metabolic reactions were initiated by the addition of $10 \mu \mathrm{L}$ NADPH $(20 \mathrm{mM})$. Total volume of the reaction suspension was $200 \mu \mathrm{L}$ and no organic solvent was added into the system. The reaction was terminated after $0,30,60,120$, and $180 \mathrm{~min}$ of incubation with $200 \mu \mathrm{L}$ of ice-cold acetonitrile:methanol mixture (1:1). Next, the precipitated samples were centrifuged at 15,000 rpm for $10 \mathrm{~min}$ at $4{ }^{\circ} \mathrm{C}$ (Eppendorf 5424R, Hamburg, Germany) and the supernatants $(50 \mu \mathrm{L})$ were transferred into autosampler vials for LC-MS analysis. The negative control samples were prepared as described above without the addition of NADPH solution.

\subsection{Analytical Procedures}

The LC-MS analysis was performed with the use of an Agilent Accurate-Mass Q-TOF LC/MS G6520B system with a dual electrospray (DESI) ionization source and Infinity 1290 ultra-high-pressure liquid chromatography system consisting of binary pump G4220A, FC/ALS thermostat G1330B, autosampler G4226A, DAD detector G4212A, TCC G1316C module (Agilent Technologies, Santa Clara, CA, USA), and a Kinetex C18 $(2.1 \times 50 \mathrm{~mm}, \mathrm{dp}=1.7 \mu \mathrm{m})$ column with a C18 precolumn guard (Phenomenex, Torrance, CA, USA). A mixture of water containing a $0.1 \%$ solution of formic acid with $5 \%$ addition of acetonitrile (A), and acetonitrile (B) was used as a mobile phase. The gradient elution was carried out at a constant flow $0.3 \mathrm{~mL} \mathrm{~min}^{-1}$ from $95 \% \mathrm{~A}(5 \% \mathrm{~B})$ to $85 \% \mathrm{~A}(15 \% \mathrm{~B})$ for $0-9$ min, then 
to $5 \% \mathrm{~A}(95 \% \mathrm{~B}) 9-9.50 \mathrm{~min}$, and a $1.50 \mathrm{~min}$ post time was performed to return to initial conditions. The injection volume was $2.0 \mu \mathrm{L}$ and the column temperature was maintained at $35^{\circ} \mathrm{C}$. MassHunter workstation software in version B.08.00 was used for the control of the system, data acquisition, qualitative, and quantitative analysis.

The optimization of the instrument conditions started with the proper tuning of the Q-TOF detector in a positive mode with the use of an Agilent ESI-L tuning mix in the extended dynamic range ( $2 \mathrm{GHz}$ ). The following instrument settings were applied: gas temp.: $325^{\circ} \mathrm{C}$, drying gas: $10 \mathrm{~L} / \mathrm{min}$, nebulizer pressure: $40 \mathrm{psig}$, capillary voltage: $3500 \mathrm{~V}$, fragmentor voltage: $175 \mathrm{~V}$, skimmer voltage: $65 \mathrm{~V}$, octopole $1 \mathrm{RF}$ voltage: $750 \mathrm{~V}$.

Data acquisition was performed in centroids with the use of TOF (MS) and auto MS/MS mode. The spectral parameters for both modes were: mass range: $60-950 \mathrm{~m} / \mathrm{z}$ and the acquisition rate: $2.0 \mathrm{spectra} / \mathrm{s}$. To ensure accuracy in the mass measurements, a reference mass correction was used and the masses of 121.050873 and 922.009798 were used as lock masses.

Semi-preparative chromatography was executed with the use of a Shimadzu UFLC (ultra-fast liquid chromatography) system consisting of: pump LC-20 AD, degassing DGU-20A5R, column oven CTO-10AS VP, DAD detector SPD-M20A (Shimadzu Corporation, Kyoto, Japan), and Zorbax SB-C18 $(9.4 \times 150 \mathrm{~mm}, \mathrm{dp}=5 \mu \mathrm{m})$ semi-preparative column (Agilent, Santa Clara, CA, USA). A mixture of water with the addition of $0.1 \%$ solution of formic acid and acetonitrile $(96.5: 3.5, v / v)$ was used as the mobile phase. The isocratic elution was carried out at a flow of $4 \mathrm{~mL} \mathrm{~min}^{-1}$ for $65 \mathrm{~min}$. The injection volume was $500 \mu \mathrm{L}$, and the column temperature was maintained at $30^{\circ} \mathrm{C}$. A Gilson FC 203B (Gilson Inc., Middleton, WI, USA) fraction collector was used to collect the proper fraction containing the M1 metabolite. The received fifteen fractions were pooled and evaporated using a Hei-VAP Value G3 rotary evaporator (Heidolph, Schwabach, Germany) under 50 mbar vacuum at a temperature of $35^{\circ} \mathrm{C}$. The residue was dissolved in $2 \mathrm{~mL}$ of acetonitrile and evaporated under the nitrogen stream. Identity and purity of the residuals were controlled using the LC-MS, and then NMR analyses were performed.

The NMR spectra were recorded on a Bruker Avance III (500 MHz, Bruker, Billerica, MA, USA) spectrometer. Chemical shifts are given in parts per million $(\delta)$ downfield from tetramethylsilane as the internal standard. Methanol- $d_{4}$ was used as the solvent.

\subsection{Chemometric Analysis}

Four metabolism experiments: HLM (after $120 \mathrm{~min}$ of incubation), control sample (HLM without $\mathrm{NADPH}), \mathrm{WO}_{3}$ photocatalytic (after $5 \mathrm{~min}$ of irradiation), and $\mathrm{WS}_{2}$ photocatalytic (after $30 \mathrm{~min}$ of irradiation) were performed in six replications for each experiment. In this manner, a set of twenty four samples for four different experiments for one of the tested drugs was obtained. For all of these samples, high resolution LC-MS analysis was performed in TOF (MS) mode and their specific chromatographic/spectral profiles were recorded. The molecular feature extraction (MFE) algorithm from the Mass Hunter Qualitative Analysis software version B.06.00 (Agilent) was used for data background ion noise cleaning and to extract the list of the ion characteristics for the metabolite profiles of the analyzed substances. The MFE parameters were optimized and the following settings were applied: single charge state of the analyzed ions, more than 2000 counts for the compound filter; isotope model: common organic molecules with peak spacing tolerance $0.0025 \mathrm{~m} / \mathrm{z}$. In order to perform the multivariate chemometric analysis, the obtained results were then exported to the Mass Profiler Professional (MPP) software version 12.61 (Agilent and Strand Life Sciences Pvt. Ltd., Santa Clara, CA, USA. With the use of this software, the data were normalized and aligned, and the principal component analysis (PCA) was performed.

\section{Conclusions}

The characterization of six, previously not described metabolites of molindone was the main accomplishment of this study. Tungsten disulfide was successfully introduced in the drug metabolism simulation, however, tungsten oxide (VI) provided a better reproduction of the metabolic profile in 
accordance with applied multivariate chemometric comparison. Moreover, the photocatalysis was utilized for the first time as a noteworthy technique in drug metabolite synthesis in order for possible future isolation and research.

The obtained high-resolution MS/MS spectra were found to hold a peculiar value in drug metabolite identification. The UHPLC-ESI-Q-TOF MS combined system proved its usefulness as a preferred analytical tool in drug metabolism studies.

Supplementary Materials: The following are available online: Figure S1: MS/MS spectrum and fragmentation pathway of molindone, Figure S2: MS/MS spectrum and fragmentation pathway of M1, Figure S3: MS/MS spectrum and fragmentation pathway of M2, Figure S4: MS/MS spectrum and fragmentation pathway of M3, Figure S5: MS/MS spectrum and fragmentation pathway of M4, Figure S6: MS/MS spectrum and fragmentation pathway of M5, Figure S7: MS/MS spectrum and fragmentation pathway of M6,

Author Contributions: Formal analysis, M.G., V.S. and M.J.; Investigation, M.G. and R.S.; Methodology, R.S.; Supervision, R.S.; Writing-original draft, M.G. and R.S.; Writing-review \& editing, V.S. and R.S. All authors have read and agreed to the published version of the manuscript.

Funding: This research received no external funding

Conflicts of Interest: The authors declare no conflicts of interest.

\section{References}

1. Krishna, G.; Gopalakrishnan, G.; Goel, S. In vitro and in vivo genotoxicity assessment of the dopamine receptor antagonist molindone hydrochloride. Environ. Mol. Mutagen. 2016, 57, 288-298. [CrossRef] [PubMed]

2. Krishna, G.; Gopalakrishnan, G.; Goel, S. Toxicity assessment of molindone hydrochloride, a dopamine D2/D5 receptor antagonist in juvenile and adult rats. Toxicol. Mech. Methods 2017, 27, 352-362. [CrossRef] [PubMed]

3. Stocks, J.D.K.; Taneja, B.; Baroldi, P.L.; Findling, R. A Phase 2a Randomized, Parallel Group, Dose-Ranging Study of Molindone in Children with Attention-Deficit/Hyperactivity Disorder and Persistent, Serious Conduct Problems. J. Child. Adolesc. Psychopharmacol. 2012, 22, 102-111. [CrossRef] [PubMed]

4. Patel, K.R.; Cherian, J.; Gohil, K.; Atkinson, D. Schizophrenia: Overview and Treatment Options. Pharm. Ther. 2014, 39, 638-645.

5. Kapur, S. Psychosis as a State of Aberrant Salience: A Framework Linking Biology, Phenomenology, and Pharmacology in Schizophrenia. Am. J. Psychiatry 2003, 160, 13-23. [CrossRef]

6. Yu, C.; Gopalakrishnan, G. In Vitro Pharmacological Characterization of SPN-810M (Molindone). Available online: https://www.dovepress.com/in-vitro-pharmacological-characterization-of-spn-810m-molindonepeer-reviewed-article-JEP (accessed on 5 October 2019).

7. Van Os, J.; Kapur, S. Schizophrenia. Lancet 2009, 374, 635-645. [CrossRef]

8. Howes, O.D.; Kapur, S. The Dopamine Hypothesis of Schizophrenia: Version III-The Final Common Pathway. Schizophr. Bull. 2009, 35, 549-562. [CrossRef] [PubMed]

9. Robinson, S.E.; Berney, S.; Mishra, R.; Sulser, F. The relative role of dopamine and norepinephrine receptor blockade in the action of antipsychotic drugs: Metoclopramide, thiethylperazine, and molindone as pharmacological tools. Psychopharmacology 1979, 64, 141-147. [CrossRef] [PubMed]

10. Sugerman, A.A.; Herrmann, J. Molindone: An indole derivative with antipsychotic activity. Clin. Pharmacol. Ther. 1967, 8, 261-265. [CrossRef] [PubMed]

11. Glazer, W.M.; Hafez, H. A comparison of masking effects of haloperidol versus molindone in tardive dyskinesia. Schizophr. Res. 1990, 3, 315-320. [CrossRef]

12. Koller, W.; Curtin, J.; Fields, J. Molindone compared to haloperidol in a guinea-pig model of tardive dyskinesia. Neuropharmacology 1984, 23, 1191-1194. [CrossRef]

13. Flammia, D.D.; Bateman, H.R.; Saady, J.J.; Christensen, E.D. Tissue Distribution of Molidone in a Multidrug Overdose. J. Anal. Toxicol. 2004, 28, 533-536. [CrossRef] [PubMed]

14. Bhatia, S.C.; Banta, L.E.; Ehrlich, D.W. Molindone and Hepatotoxicity. Drug Intell. Clin. Pharm. 1985, 19, 744-746. [CrossRef] [PubMed] 
15. McCue, R.E.; Unuigbe, F.E.; Charles, R.A.; Orendain, G.C.M.; Waheed, R. Treatment of Morbidly Obese Psychotic Patients with Molindone: Three Case Reports. J. Clin. Psychiatry 2009, 70, 1606-1607. [CrossRef] [PubMed]

16. Bagnall, A.-M.; Fenton, M.; Kleijnen, J.; Lewis, R. Molindone for schizophrenia and severe mental illness. Cochrane Database Syst. Rev. 2007. [CrossRef] [PubMed]

17. Kumar, G.N.; Surapaneni, S. Role of drug metabolism in drug discovery and development. Med. Res. Rev. 2001, 21, 397-411. [CrossRef]

18. Jaeschke, H.; Gores, G.J.; Cederbaum, A.I.; Hinson, J.A.; Pessayre, D.; Lemasters, J.J. Mechanisms of Hepatotoxicity. Toxicol. Sci. 2002, 65, 166-176. [CrossRef]

19. David, S.; Hamilton, J.P. Drug-induced Liver Injury. US Gastroenterol. Hepatol. Rev. 2010, 6, 73-80.

20. Njoku, D.B. Drug-Induced Hepatotoxicity: Metabolic, Genetic and Immunological Basis. Int. J. Mol. Sci. 2014, 15, 6990-7003. [CrossRef]

21. Asha, S.; Vidyavathi, M. Role of human liver microsomes in in vitro metabolism of drugs-A review. Appl. Biochem. Biotechnol. 2010, 160, 1699-1722. [CrossRef]

22. Lee, J.-Y.; Choi, Y.J.; Oh, S.J.; Chi, Y.H.; Paik, S.H.; Lee, K.H.; Jung, J.-K.; Ryu, C.S.; Kim, K.-B.; Kim, D.-H.; et al. Characterization of fimasartan metabolites in human liver microsomes and human plasma. Xenobiotica 2016, 46, 40-51. [CrossRef] [PubMed]

23. Lang, D.; Freudenberger, C.; Weinz, C. In Vitro Metabolism of Rivaroxaban, an Oral, Direct Factor Xa Inhibitor, in Liver Microsomes and Hepatocytes of Rats, Dogs, and Humans. Drug Metab. Dispos. 2009, 37, 1046-1055. [CrossRef] [PubMed]

24. Metabolism Study and Biological Evaluation of Bosentan Derivatives|Elsevier Enhanced Reader. Available online: https://reader.elsevier.com/reader/sd/pii/S0223523416304834?token= 4357C7C17B76634A86BC9152B3E97D3394109F6110507C92AA2991D7FBF0CD73A3888B5CCEF74 E2E0E969858250D04B1 (accessed on 28 October 2019).

25. Zhuo, X.; Zheng, N. Drug Metabolism | Metabolite Isolation and Identification. In Encyclopedia of Analytical Science, 3rd ed.; Worsfold, P., Poole, C., Townshend, A., Miró, M., Eds.; Academic Press: Oxford, UK, 2019; pp. 232-239, ISBN 978-0-08-101984-9.

26. Baranczewski, P.; Stańczak, A.; Sundberg, K.; Svensson, R.; Wallin, A.; Jansson, J.; Garberg, P.; Postlind, H. Introduction to in vitro estimation of metabolic stability and drug interactions of new chemical entities in drug discovery and development. Pharmacol. Rep. 2006, 58, 453-472. [PubMed]

27. Morgan, S.; Grootendorst, P.; Lexchin, J.; Cunningham, C.; Greyson, D. The cost of drug development: A systematic review. Health Policy 2011, 100, 4-17. [CrossRef]

28. Calza, P.; Pelizzetti, E.; Brussino, M.; Baiocchi, C. Ion trap tandem mass spectrometry study of dexamethasone transformation products on light activated $\mathrm{TiO}_{2}$ surface. J. Am. Soc. Mass Spectrom. 2001, 12, 1286-1295. [CrossRef]

29. Calza, P.; Pazzi, M.; Medana, C.; Baiocchi, C.; Pelizzetti, E. The photocatalytic process as a tool to identify metabolitic products formed from dopant substances: The case of buspirone. J. Pharm. Biomed. Anal. 2004, 35, 9-19. [CrossRef]

30. Medana, C.; Calza, P.; Giancotti, V.; Bello, F.D.; Pasello, E.; Montana, M.; Baiocchi, C. Horse metabolism and the photocatalytic process as a tool to identify metabolic products formed from dopant substances: The case of sildenafil. Drug Test. Anal. 2011, 3, 724-734. [CrossRef]

31. Fujishima, A.; Honda, K. Electrochemical Photolysis of Water at a Semiconductor Electrode. Nature 1972, 238, 37. [CrossRef]

32. Hashimoto, K.; Irie, H.; Fujishima, A. $\mathrm{TiO}_{2}$ Photocatalysis: A Historical Overview and Future Prospects. Jpn. J. Appl. Phys. 2005, 44, 8269. [CrossRef]

33. Gawlik, M.; Trawiński, J.; Skibiński, R. Simulation of phase I metabolism reactions of selected calcium channel blockers by human liver microsomes and photochemical methods with the use of Q-TOF LC/MS. J. Pharm. Biomed. Anal. 2019, 175, 112776. [CrossRef]

34. Gawlik, M.; Trawiński, J.; Skibiński, R. Photocatalysis as a Tool for in Vitro Drug Metabolism Simulation: Multivariate Comparison of Twelve Metal Oxides on a Set of Twenty Model Drugs. Catalysts 2020, 10, 26. [CrossRef]

35. Gul, T.; Bischoff, R.; Permentier, H.P. Electrosynthesis methods and approaches for the preparative production of metabolites from parent drugs. TrAC Trends Anal. Chem. 2015, 70, 58-66. [CrossRef] 
36. Valentová, K.; Káňová, K.; Di Meo, F.; Pelantová, H.; Chambers, C.S.; Rydlová, L.; Petrásková, L.; Křenková, A.; Cvačka, J.; Trouillas, P.; et al. Chemoenzymatic Preparation and Biophysical Properties of Sulfated Quercetin Metabolites. Int. J. Mol. Sci. 2017, 18, 2231.

37. Mukai, K.; de Sant'Ana, D.P.; Hirooka, Y.; Mercado-Marin, E.V.; Stephens, D.E.; Kou, K.G.M.; Richter, S.C.; Kelley, N.; Sarpong, R. Bioinspired chemical synthesis of monomeric and dimeric stephacidin A congeners. Nat. Chem. 2018, 10, 38-44. [CrossRef] [PubMed]

38. Bioreactor Systems in Drug Metabolism: Synthesis of Cytochrome P450-Generated Metabolites|Elsevier Enhanced Reader. Available online: https://reader.elsevier.com/reader/sd/pii/S1096717600901472?token= 7F42B63F45A09779997B4069F89536C73627361C2FAEDB42F9CF7608F19CDB6C98140D2A81789F3DBE 34BAE0ED793480 (accessed on 5 February 2020).

39. Johansson, T.; Weidolf, L.; Jurva, U. Mimicry of phase I drug metabolism-Novel methods for metabolite characterization and synthesis. Rapid Commun. Mass Spectrom. 2007, 21, 2323-2331. [CrossRef]

40. Zhao, J.; He, X.; Yang, N.; Sun, L.; Li, G. Study of Drug Metabolism by Xanthine Oxidase. Int. J. Mol. Sci. 2012, 13, 4873-4879. [CrossRef]

41. Wen, B. Mass Spectrometry in Drug Metabolism: Principles and Common Practice. In Encyclopedia of Spectroscopy and Spectrometry, 3rd ed.; Lindon, J.C., Tranter, G.E., Koppenaal, D.W., Eds.; Academic Press: Oxford, UK, 2017; pp. 728-734, ISBN 978-0-12-803224-4.

42. Li, F.; Gonzalez, F.J.; Ma, X. LC-MS-based Metabolomics in Profiling of Drug Metabolism and Bioactivation. Acta Pharm. Sin. B 2012, 2, 118. [CrossRef]

43. Bell, J.D.; Gadian, D.G.; Preece, N.E. NMR studies of drug metabolism and disposition. Eur. J. Drug Metab. Pharmacokinet. 1990, 15, 127-133. [CrossRef]

44. Kim, J.-H.; Choi, W.-G.; Lee, S.; Lee, H.S. Revisiting the Metabolism and Bioactivation of Ketoconazole in Human and Mouse Using Liquid Chromatography-Mass Spectrometry-Based Metabolomics. Int. J. Mol. Sci. 2017, 18, 621. [CrossRef]

Sample Availability: Samples of the compounds are not available from the authors.

(C) 2020 by the authors. Licensee MDPI, Basel, Switzerland. This article is an open access article distributed under the terms and conditions of the Creative Commons Attribution (CC BY) license (http://creativecommons.org/licenses/by/4.0/). 